\title{
PELATIHAN REGULASI EMOSI UNTUK REMAJA HARAPAN MULYA KEMAYORAN
}

\author{
Johan Satria Putra ${ }^{1}$, Ade Nursanti ${ }^{2}$, Karimulloh $^{3}$ \\ ${ }^{1,2,3}$ Program Studi Psikologi, Fakultas Psikolog, Universitas YARSI \\ Email: johansatriaputra@gmail.com
}

\begin{abstract}
One of the common social problems in Jakarta is a people chaos and brawl between societies. Some cases that often occured in the Central Jakarta area, most of the motives of residents who participated in the brawl were not certain, and also from which communities or regions they came from. Most of the brawlers are teenagers. Teenagers are in a period of an unstable emotional conditions so that easily provoked to follow brawls without knowing the root of the problem and its consequences. Brawl is a form of mass aggression. One of the factors of drives aggression is the regulation of emotions which are not good and right. Therefore, the intervention model that will be applied to adolescents in community service is group emotional regulation training. This training program is carried out for a full day, including induction and release of negative emotions, sharing knowledge about emotions and regulation, and stimulating positive emotions. The training was given to 17 teenagers from the Harapan Mulya village neighborhood, especially from Forum Remaja (Local Youth Forum). Measurement of emotional changes and the level of aggressiveness is examined by giving pre and post-test before and after training, using the scale of Aggression and VAS. The results of statistical analysis show that the average score of aggressiveness decreased after being given training. It means that the emotion regulation training was effectively reduce the aggressiveness of the adolescence.
\end{abstract}

Keywords: Adolescence, Aggression, Emotion Regulation Training

\begin{abstract}
Abstrak. Salah satu permasalahan sosial yang jamak terjadi di daerah Jakarta adalah tawuran antar warga. Seperti kasus yang sering muncul di daerah Jakarta Pusat, kebanyakan dari warga yang mengikuti tawuran tersebut tidak diketahui secara pasti motifnya dan dari kelompok atau wilayah mana yang bersangkutan berasal. Sebagian besar pelaku tawuran tersebut adalah remaja. Remaja berada pada masa kondisi emosi yang labil sehingga mudah terprovokasi untuk mengikuti tawuran tanpa mengetahui akar masalah dan konsekuensinya. Tawuran merupakan bentuk agresi massa, di mana salah satu faktor yang mendorong agresi adalah regulasi emosi yang kurang baik dan tepat. Oleh karena itu, model intervensi yang akan diterapkan pada para remaja dalam pengabdian pada masyarakat ini adalah pelatihan regulasi emosi kelompok. Program pelatihan ini dilaksanakan selama sehari penuh, meliputi induksi dan pelepasan emosi negatif, pemberian materi tentang emosi dan regulasinya, serta stimulasi emosi positif. Pelatihan diberikan kepada 17 orang remaja dari lingkugan kelurahan Harapan Mulya, khususnya Forum Remaja setempat. Pengukuran perubahan emosi dan tingkat agresivitas dilakukan dengan memberikan pre dan post-test sebelum dan sesudah pelatihan, menggunakan skala Agresi dan VAS. Hasil analisis statistik dengan melihat perubahan rata-rata skor antara pre dan post-test menunjukkan penurunan tingkat agresivitas setelah diberikan pelatihan.
\end{abstract}

Kata kunci : Agresi, Pelatihan Regulasi Emosi, Remaja

\section{PENDAHULUAN}

Tawuran antar kelompok merupakan suatu fenomena yang telah jamak terjadi di Indonesia. Umumnya tawuran melibatkan perkelahian antar sekolah atau bentrok antar suporter sepakbola. Namun, tidak jarang juga yang ikut serta dalam suatu tawuran adalah warga atau masyarakat umum. Sebagaimana yang sering terjadi di ibukota DKI Jakarta. Tidak hanya di satu dua lokasi saja, tawuran antar warga dapat terjadi nyaris di semua titik di Jakarta dan bahkan dengan frekuensi kejadian hampir setiap bulan. Beberapa daerah yang rawan tawuran antara lain seperti Manggarai, Palmerah, Bendungan Hilir, hingga Pasar Rumput (cnnindonesia.com, vice.com).

Jakarta Pusat sendiri meruapakan salah satu daerah yang rawan tawuran di DKI. Dikutip dari berbagai sumber, intensitas tawuran di Jakarta Pusat tergolong tinggi. Seperti tawuran yang terjadi pada awal Juni 2018 lalu menjelang sahur, tawuran antar dua kelompok pada 2 Januari 2018, tawuran pada September 2017 yang diduga karena terkait narkoba, hingga yang 
terbaru adalah tawuran pada Sabtu tanggal 11 Agustus malam lalu. Penyebab dari berbagai tawuran yang terjadi ini pun seringkali tidak diketahui secara jelas. Seperti berdasarkan hasil wawancara penulis dengan pengelola RPTRA Pulo Gundul yang berlokasi di kelurahan Tanah Tinggi, Johar Baru, warga sekitar sering mengikuti tawuran tanpa alasan yang jelas (detik.com). Kesalahpahaman atau perdebatan ditengarai menjadi faktor utama. Sebagian besar warga yang mengikuti tawuran tersebut masih berusia remaja, yaitu mulai dari usia SMP hingga mereka yang baru lulus dari SMA.

Tawuran atau perkelahian antar kelompok merupakan suatu bentuk perilaku agresi dalam lingkup massa. Perilaku agresi sendiri merupakan suatu implikasi dari adanya regulasi atau manajemen emosi yang kurang baik. Apabila agresifitas itu terjadi dalam lingkup massa, maka dalam hal ini emosi yang terlibat adalah emosi kelompok. Tahapan perkembangan manusia di mana seseorang memiliki emosi yang labil adalah pada masa remaja. Berdasarkan berbagai kasus tawuran yang terjadi di wilayah Jakarta Pusat, belum diketahui secara pasti faktor apa saja yang mempengaruhi perilaku tawuran tersebut. Namun, menilik dari tahapan perkembangan emosi remaja yang mudah labil, maka dimungkinkan perilaku tawuran atau agresi yang muncul adalah dikarenakan kurangnya kemampuan dalam mengelola emosi pada remaja sehingga mudah terprovokasi atau terpancing untuk turut serta dalam tawuran yang terjadi.

Salah satu permasalahan sosial yang terjadi pada masyarakat ibukota Jakarta adalah tawuran antar warga. Sebagian besar dari warga yang terlibat tawuran masih berusia remaja, di mana remaja sendiri berada pada masa perkembangan emosi yang labil dan mudah terprovokasi untuk melakukan perilaku agresi. Penyebab utama dari perilaku agresi dan emosi yang labil adalah kurangnya kemampuan untuk mengelola emosi atau regulasi emosi. Oleh karena itu, salah satu metode intervensi yang dapat diberikan untuk membantu remaja dalam mengelola emosinya adalah dengan pelatihan regulasi emosi. Dikarenakan perilaku agresi dalam kasus ini adalah tawuran atau agresi massa, maka pelatihan regulasi emosi di sini lebih ditekankan pada emosi kelompok.

\section{Tujuan dan Manfaat Kegiatan}

Tujuan pelatihan ini adalah untuk meningkatkan kemampuan regulasi emosi kelompok pada remaja di wilayah Harapan Mulya. Melalui pelatihan yang diberikan, diharapkan para remaja akan memiliki regulasi emosi yang baik, sehingga tidak mudah terprovokasi untuk mengikuti kegiatan tawuran. Dengan demikian, angka tawuran dapat tereduksi.

\section{METODE PELAKSANAAN}

Program ini akan dilakukan dalam bentuk pelatihan, yang akan dilaksanakan selama satu hari. Program ini dilaksanakan di RPTRA Harapan Mulya, Kemayoran, pada tanggal 16 Maret 2019, pukul 08.00 hingga 14.00 WIB. Peserta merupakan remaja yang tinggal di seputaran lingkungan Harapan Mulya. Jumlah total peserta adalah 17 orang, yang terdiri dari 4 putra dan 13 putri, dengan rentang usia dari 1517 tahun. Gross dan Thompson (2007) mengemukakan dua strategi regulasi emosi, yaitu cognitive reappraisal dan expressive suppression. Berdasarkan konsep dasar tersebut ditambah dengan panduan dari Emotion Regulation Training oleh Schuppert, dkk. (2009), maka pelatihan ini akan melalui beberapa sesi, yaitu :

1. Pemodelan kognitif. Pada sesi ini, peserta akan diajak untuk menganalisis pola pikirnya sendiri selama ini, seperti benar tidaknya halhal yang pernah dia lakukan di masyarakat, membedakan hal yang penting dan tidakpenting, dan sebagainya.

2. Stimulasi emosi. Pada sesi ini, peserta diminta untuk mengekspresikan emosi yang dia rasakan melalui media yang positif dan menyenangkan.

3. Komunikasi interpersonal. Pada sesi ini, peserta dilatih untuk mampu menyampaikan pendapat maupun emosinya dengan cara yang lebih asertif dan tepat.

Rangkaian kegiatan pelatihan dibuka dengan pembukaan dan ice breaking yang diberikan oleh mahasiswa. Setelah itu diberikan pre-test, yaitu peserta diminta mengisi skala Agression Questionnaire dan VAS. Setelah itu 
dilanjutkan pemberian materi yang pertama, yaitu mengenai konsep dasar emosi. Setelah pemberian materi, peserta dipertontonkan tiga buah video yang tujuannya adalah menginduksi emosi negatif dari peserta. Induksi emosi negatif diperkuat dengan pengisian lembar emosi negatif di mana peserta diminta menuangkan keluhan, perasaan kekurangan, dan ketidakpuasan terhadap hidupnya.

Setelah itu dilanjutkan dengan sesi perenungan, yaitu peserta diajak untuk mengimajinasikan sedang bertemu dengan seseorang yang memiliki konflik dengan yang bersangkutan, untuk kemudian mengkatarsiskan dan melepaskan segala emosi negatifnya. Setelah melakukan perenungan, peserta diminta membuang segala emosi negatif yang telah mereka tulis sebelumnya ke sebuah kotak, sebagai simbol dari pelepasan segala emosi negatif yang mereka rasakan.

Kemudian kegiatan pelatihan memasuki sesi inti, yaitu materi mengenai cara meregulasi emosi. Setelah mendapat materi, peserta kemudian diminta mengisi lembar kerja emosi positif, dengan tujuan untuk menginduksi emosiemosi positif dari diri peserta. Pelatihan ditutup dengan materi mengenai marah menurut islam dan cara mengatasinya. Sebelum pulang, peserta terlebih dahulu mengisi post-test berupa skala VAS dan Agression Questionnaire, ditambah form evaluasi pelatihan dan pengetahuan mengenai materi yang diberikan.

\section{Rancangan evaluasi}

Terdapat dua alat ukur yang digunakan dalam evaluasi pelatihan ini, yaitu skala Aggression Questionnaire (Buss \& Perry, 1992) dan Visual Analog Scale (Carlsson, 1983). Aggression Questionnaire diberikan sebelum dan sesudah pelatihan, kemudian akan dianalisis secara statistik perubahan mean skor agresi peserta sebelum dan sesudah pelatihan untuk melihat perubahan agresifitas peserta setelah diberikan pelatihan. Visual Analog Scale diberikan sebelum pelatihan, setelah induksi emosi negatif, dan setelah pelatihan. Setelah itu dianalisis secara statistik perubahan ekspresi emosi yang diberikan, untuk melihat perubahan emosi yang dialami peserta sebagai efek dari pemberian pelatihan.

\section{HASIL DAN PEMBAHASAN}

Evaluasi kegiatan yang diberikan oleh peserta menunjukkan, sebanyak $66,67 \%$ peserta sangat puas dan 33,33\% menyatakan puas dengan manfaat pelatihan yang diberikan. Terkait kejelasan materi dan fasilitas kegiatan, mayoritas peserta juga menyatakan puas. Sementara terdapat 3 orang atau $16,67 \%$ peserta yang merasa waktu pelaksanaan pelatihan kurang memuaskan. Hasil evaluasi kegiatan selengkapnya dapat dilihat pada tabel 1 .

Berdasarkan pre dan post-test yang diberikan, ditemukan bahwa mean atau rata-rata skor agresi yang diperoleh peserta menurun dari 92,86 menjadi 92,50. Hasil ini menunjukkan bahwa tingkat agresivitas peserta menurun setelah diberikan pelatihan regulasi emosi. Hasil ini serupa dengan hasil pelatihan yang dilakukan oleh Puspadewi (2014) yang juga melakukan pelatihan regulasi emosi untuk mengurangi perilaku agresi pada remaja SMK. Efek pelatihan terhadap agresifitas ini dapat dilihat pada Gambar 1. 


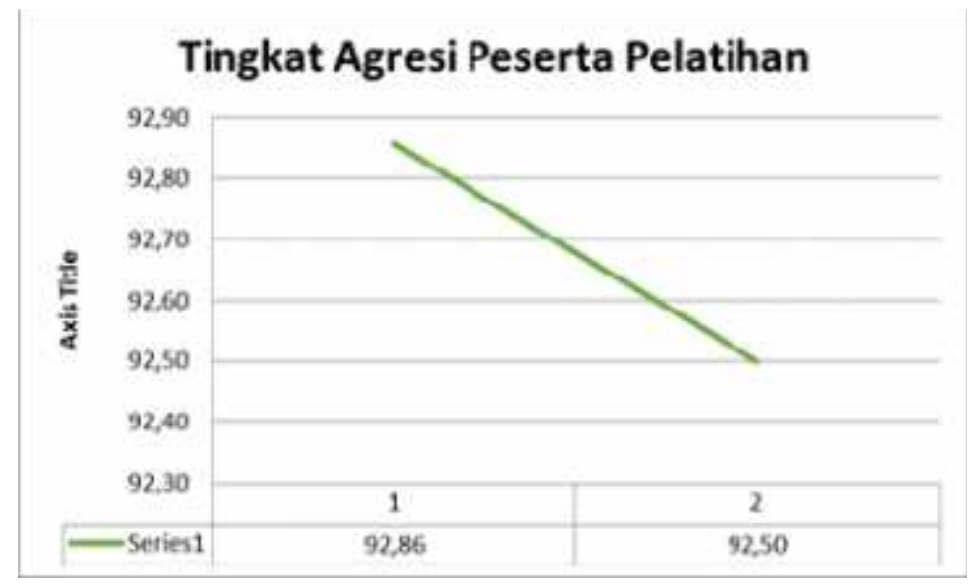

Gambar 1. Hasil pengukuran perubahan perilaku agresi

Regulasi emosi dapat diartikan sebagai suatu strategi yang mencakup pikiran alam bawah sadar maupun pikiran sadar untuk mengkontrol respons emosi pada situasi tertentu (Gross \& John, 2003). Seseorang yang kurang baik dalam meregulasi emosi, umumnya akan cenderung mudah terangsang oleh situasi yang sulit, tidak mampu menahan perasaan untuk menyerang, tidak dapat mengambil keputusan yang tepat, dan pada akhirnya maka perilaku agresi pun muncul (Roberton, Daffern, \& Bucks, 2012). Oleh karena itu, dibutuhkan manajemen terhadap emosi yang ada, khususnya adalah emosi negatif seperti marah (Hestiningrum, 2016)

Di sisi lain, skor VAS yang diperoleh peserta meningkat dari 6,72 menjadi 7,36. Hasil ini menunjukkan bahwa peserta mengalami peningkatkan emosi positif setelah diberi pelatihan regulasi emosi. Secara teoritis, umumnya perilaku agresi dapat disebabkan oleh faktor-faktor eksternal seperti pemaparan model agresi, provokasi, atau internalisasi nilai-nilai pro agresi. Salah satu emosi yang dapat mendorong seseorang melakukan agresi adalah emosi marah. Seseorang yang berada dalam kondisi marah, akan lebih mudah melakukan agresi, terutama apabila terdapat provokasi dari pihak luar (Roberton, Daffern, \& Bucks, 2012). Inilah yang menyebabkan emosi positif peserta sempat menurun setelah diberikan induksi emosi negatif. Namun, berbagai faktor eksternal tidak dapat secara otomatis mendorong perilaku agresi, tanpa adanya kondisi afektif atau emosi tertentu yang dimiliki oleh individu yang bersangkutan (Baron \& Byrne, 2004). Dalam hal ini, emosi marah dapat terjadi dikarenakan adanya kekurang mampuan dalam melakukan regulasi terhadap emosi diri. Sehingga pelatihan regulasi emosi ini juga efektif untuk menurunkan emosi neagtif, sekaligus meningkatkan emosi positif. Efek pelatihan terhadap emosi positif dapat dilihat pada Gambar 2

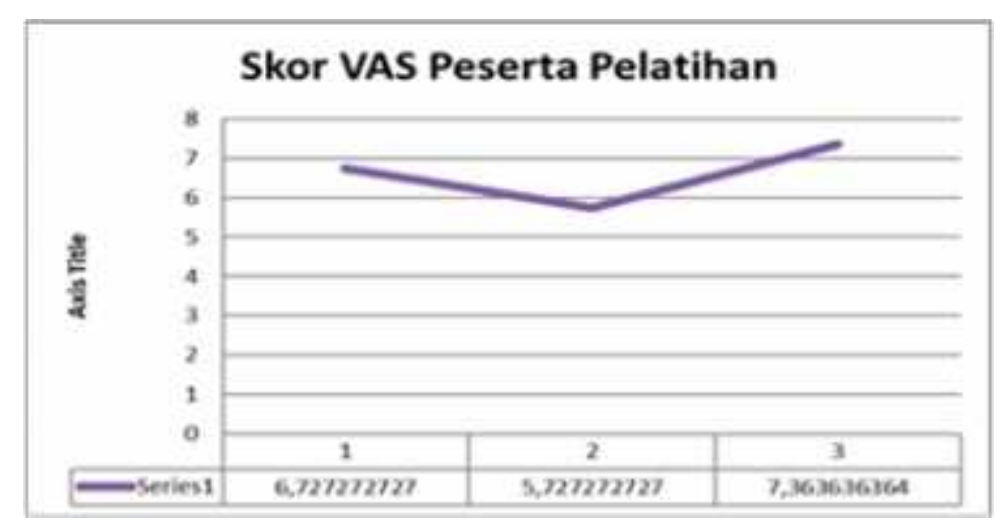

Gambar 2. Hasil Pengukuran Perubahan Emosi Positif 
Hasil analisis evaluasi pelatihan menunjukkan bahwa terdapat penurunan perilaku agresi dan peningkatan emosi positif pada peserta setelah diberi pelatihan. Perolehan ini sesuai dengan beberapa pelatihan regulasi emosi terdahulu (Puspadewi, 2014; Hestiningrum, 2016; Schuppert dkk., 2009) yang menunjukkan hasil serupa. Dengan demikian, maka dapat dikatakan bahwa tujuan pelatihan tercapai. Adapun pelatihan ini sendiri masih memiliki sejumlah kelemahan, terutama karena tidak adanya follow-up dan monitoring jangka menengah-panjang untuk melihat perkembangan perilaku agresi pada peserta. Kendala yang dialami adalah karena penulis tidak mendapatkan data yang lengkap dan jelas mengenai peserta, sehingga kesulitan untuk menghubungi kembali yang bersangkutan dalam rangka melakukan follow-up.

\section{SIMPULAN DAN SARAN}

Mengacu pada indikator kinerja serta evaluasi program, dapat disimpulkan bahwa program pelatihan regulasi emosi yang diberikan mampu secara efektif untuk menurunkan perilaku agresi dan meningkatkan emosi positif pada remaja di Harapan Mulya. Diharapkan dengan keberadaan pelatihan ini, peserta yang merasakan manfaatnya akan mampu memiliki regulasi emosi yang baik, yang dapat dioptimalkan dalam kehidupan kesehariannya, dalam rangka mencegah perilaku agresi secara pribadi maupun konflik sosial.

Berdasarkan evaluasi pelaksanaan kegiatan, terdapat hal-hal yang perlu diperhatikan apabila program pelatihan ini akan dilakukan kembali, yaitu:

1. Koordinasi dengan mitra diharapkan tidak terlalu mepet dengan target waktu pelaksanaan, sehingga dapat meminimalisir sejumlah kendala teknis seperti yang kami alami

2. Pelatihan regulasi emosi ini akan jauh lebih baik apabila dilakukan secara jangka panjang dan bertahap, sehingga dapat lebih intensif dalam memantau perubahan pada diri peserta dan akan memiliki implikasi yang lebih efektif
3. Program ini juga dapat dicoba untuk diaplikasikan tidak hanya kepada sasaran remaja, namun juga dewasa

\section{UCAPAN TERIMA KASIH}

Melalui artikel ini penulis turut mengucapkan terima kasih kepada berbagai mitra yang terlibat dalam pelaksanaan pelatihan regulasi emosi ini, terutama pengelola RPTRA Harapan Mulya, Kelurahan Harapan Mulya, Forum Remaja Harapan Mulya. Tidak lupa juga penulis haturkan terima kasih kepada pihak yayasan YARSI yang telah memberikan dukungan berupa pembiayaan program pelatihan ini melalui mekanisme hibah internal pengabdian pada masyarakat Universitas YARSI.

\section{DAFTAR PUSTAKA}

Baron, R.A \& Byrne, D. (2004). Psikologi sosial, jilid 2. Jakarta: Erlangga.

Buss, A. H. \& Perry, M. P. (1992). The Aggression questionnaire. Journal of Personality and Social Psychology, 63, 452-459.

Detik.com (2016). Polisi: sering terjadi tawuran di wilayah Johar Baru, Jakarta Pusat. Diakses dari https://news.detik.com/berita/d3318552/polisi-sering-terjadi-tawuran-diwilayah-johar-baru-jakarta-pusat pada tanggal 17 Oktober 2018.

Castillo, R., Salguero, J.M., Fernandez-Berrocal, P., \& Balluerka, N. (2013). Effects of an emotional intelligence intervention on aggression and empathy among adolescents. Journal of Adolescence, 36, 883-892.

Goldenberg, A., Halperin, E., van Zomeren, E., \& Gross, J.J. (2015). The Process Model of Group-Based Emotion: Integrating Intergroup Emotion and Emotion Regulation Perspectives. Personality and Social Psychology Revgrossiew, 1-24.

Gross, J. J., \& John, O. P. (2003). Individual Differences In Two Emotion Regulation Processes: Implications For Affect, Relationships, And Well-Being. Journal of 
Personalityand Social Psychology, 85(2), Roberton, T., Daffern, M., \& Bucks, R.S. (2012). 348-362.

Gross, J.J \& Thompson, R.A. (2007). Emotion Regulation Conceptual. Handbook of Emotion regulation and aggression. Emotion Regulation, James J. Gross (Ed). NY: Guilfors Publication

Hestiningrum. (2016). Manajemen amarah: strategi untuk mengurangi perilaku agresi siswa sekolah menengah. Prosiding Aggression and Violent Behavior, 17, 7282.

Schuppert, H.M., et.al. (2009). Effectiveness of an emotion regulation group training for adolescents-a randomized controlled pilot study. Clinical Psychological Psychoter, Seminar Nasional Konseling Krisis. $16,467-478$. 